\title{
The process of creation of the new cities in Tunisia: Case of the city of the Lake of Tunis
}

\begin{abstract}
Hagui Abdelhamid
Urban Planning, Development and Dynamic Spaces, University of Paris-Sorbonne, Ben Hadid, 26 rue de l'étoile 93000 Bobigny, France. E-mail: h_abdelhamid2@yahoo.fr.

Accepted 23 May, 2012

From 1987 up till now, the Northern Shoreline of the Lake has been almost urbanized. The importance of this space comes from the fact that it offers the urban areas aspects to look for by the different urban activities. Can we then say it is a space which has been able to escape the law of the land market matching activities of strong investment value on the most attractive places. However, by visiting the Lake we are convinced that we are in front of a space or coalesce the tertiary activities rather than another polyfonctionnel with a planned allocation as balanced between the various urban functions. It simply needs to print the real to release the gaps between the planned and the achieved. What attracted our attention during our whole investigation has been the relatively large number of closed premises in the area of the lake. Have these locations not been dedicated to urban activities yet? Or have they been open until a recent date and their closures have been dictated by the problems specific to the activity? These questions will allow us to see if the space of the lake is well utilized and the closure was for economic reasons specific to the establishments or the contrary.
\end{abstract}

Key words: Lake, Tunis, arrangement, banks, economic crisis, tertiary, activities.

\section{INTRODUCTION}

All over the world, city centers constitute the main places where people and activities are concentrated. They are the main homes of influxes of immigrants coming from outside with the aim of improving the living conditions. It is at the level of these central zones where information occurs and spreads fast, where the job offer attains these extremes and where the consumers can meet their needs.

Generally, studies led on city centers have never ceased to enrich the thought of the researchers for the purpose to delimit this centrality, to introduce these characteristics and to determine the main functionality which they contain. At this level, they were conceived as being central areas where the activities of different urban forms pile up. These are functional places where trade and services crowd together. It is in this central zone where supervision, coordination and organization attain these extremes. This functional dimension does not hide the symbolic dimension. Indeed, these areas distinguish themselves from others by their monuments and their buildings. "It would be possible to say, so, that in the symbolic picture of the city, often exists an authentic process of reduction of all urban area in the centre and in other part, an across-the-board glorification of the role of the centre considered to be the most representative element and absolutely, in the picture of the city" (Beaujeau Garnier).

All the time, these urban centers, in developed countries as well as in developing countries, converge the most important part of the problem of the city. It is in these areas where the migration pendulum records these extreme stocks, where they witness the growing problems of circulation, where still the supply of the accommodation exceeds demand widely ...

Facing difference between centre and periphery developed countries have adopted since the 1950s, a step which consists in creating new peripheral centers equipped for most of all with the necessary equipment for their independence. A new method having as objective to attenuate the hyperconcentration of activities in the central areas.

For developing countries, dualism - centre / periphery - 
remain always one of the characteristics of the urban cloth of cities. The centre has always played the role of command, of direction and of coordination; it is also the place of convergence of the fluxes of activities of property and of persons. On the contrary, periphery remains always dependent and tributary on the power exercised by the central place.

In Tunisia and till the end of 1970s, urban phenomenon knew an excessive difference between centres where the totality of the fluxes of activities and of persons converged, and a periphery abandoned and badly equipped. It is with the hyperconcentration of activities in the centre that urban problems were put forward. A situation that pushed the representatives for the action of planning to multiply efforts to deal with these problems linked to urban development. Indeed, follows in the completion of the action of cleaning up and of restoration of the Lake of Tunis and the appearance of the whole capable zone in urban use, that ideas converged on the necessity to include the banks of this man-made lake into the urban cloth of the capital.

From 1987 onwards, the North banks of the Lake have almost been urbanized. The importance of this space comes from the fact that it offers urban aspects too much sought by different urban activities. It is then possible to say it is a space which could avoid the law of the land market putting in adequacy the activities of strong value of investment on the most delightful places.

However, by visiting the Lake we are persuaded that we are in front of a space where together activities service sectors accumulated rather than another polyfonctionnel endowed with a sharing out conceived as being balanced between the various urban functions. It is enough to print the real to clear distances between the planned and the accomplished.

What drew our attention during all our inquiry was the important number of closed placed in the space of the Lake. Have not these places been devoted to an urban activity yet? Or have they been until recently opened and their closings was dictated by problems peculiar to the activity? These questionings are going to allow us to see if the space of the lake is well exploited and the closing was for economic reasons peculiar to establishments or the opposite.

Always starting from our prototype, the Lake Luxury hotel the main commercial place of this space worked up, it is not possible to visit the Lake without passing through this place. At the beginning of 1990s, this space counted 101 boutiques of luxuries specialized mostly in the trade of clothing. Places were complete and no representatives think of transferring his activity out of this space. Today, 46 places, from 101 already mentioned, are empty without any activity. By questioning the neighbors, the leaders of establishments, it seems that at present, the space of the lake does not answer the expectations of activities with strong value of investment.

\section{A "NEW TUNISIA" ON LAKE: LIKE VENICE}

More than it is a development which is made on a properly humid zone, its importance lies in the fact that it makes presence of three properly different parts to know: the State which wants to hinder techniques and methods used for the development of Lakes, the foreign investors who want to intervene to gain benefits, and the experts in the field who try to put their knowledge in the field.

Generally this development comes to frustrate the movement of urban development of Tunis which was marked by its linearity, and to produce a whole city by the waterside.

\section{The Lake: An arrangement conceived to frustrate the movement of urban development of Tunis}

Since the beginning of the 1960 s, fact to do up converges with fact to limit the distortion between regions always starting with socio-spatio-economic problems to justify any actions of urban planning.

However, since the appearance of the idea of saving the ecosystem of the Lake of Tunis and of rectifying its North banks so that they become more or less apt to the urban use, so that the Tunisian action in urban planning began its first footsteps on course for the modernization of its tools.

An action which is resolutely meant to be modernist due to the fact that it tries to benefit Tunis from a whole plan of action widely inspired by the Westerner experience, and due to the fact that this action is going to allow to change the vision in relation to the plans of waters to structure and include them into urbanization (Maps 1 and 2).

More than it comes to produce a polyfonctionnel and radiant space, the development of the Lake is explained by the fact to produce a whole new urban border for a city which was widely wedged by natural restrictions, at the level of its urban development. It is a tendency and a large-scale choice when they do up the Lake not only for the production of the whole space entity, but also to regulate the contrasts of urban development of the city and to frustrate the whole urban development to replace it with a more moderate.

Since the beginning of the appearance of the idea of building the North banks of the Lake of Tunis by an action of development to the advantage of the urbanization of the Tunisian capital, the scenarios succeeded and the ambition stays far from being accomplished because of the financial inability of the State to take care of this expensive operation.

The most important scenario was introduced by the Tunisian architect O.-C. Cacoub, a close to the Tunisian 


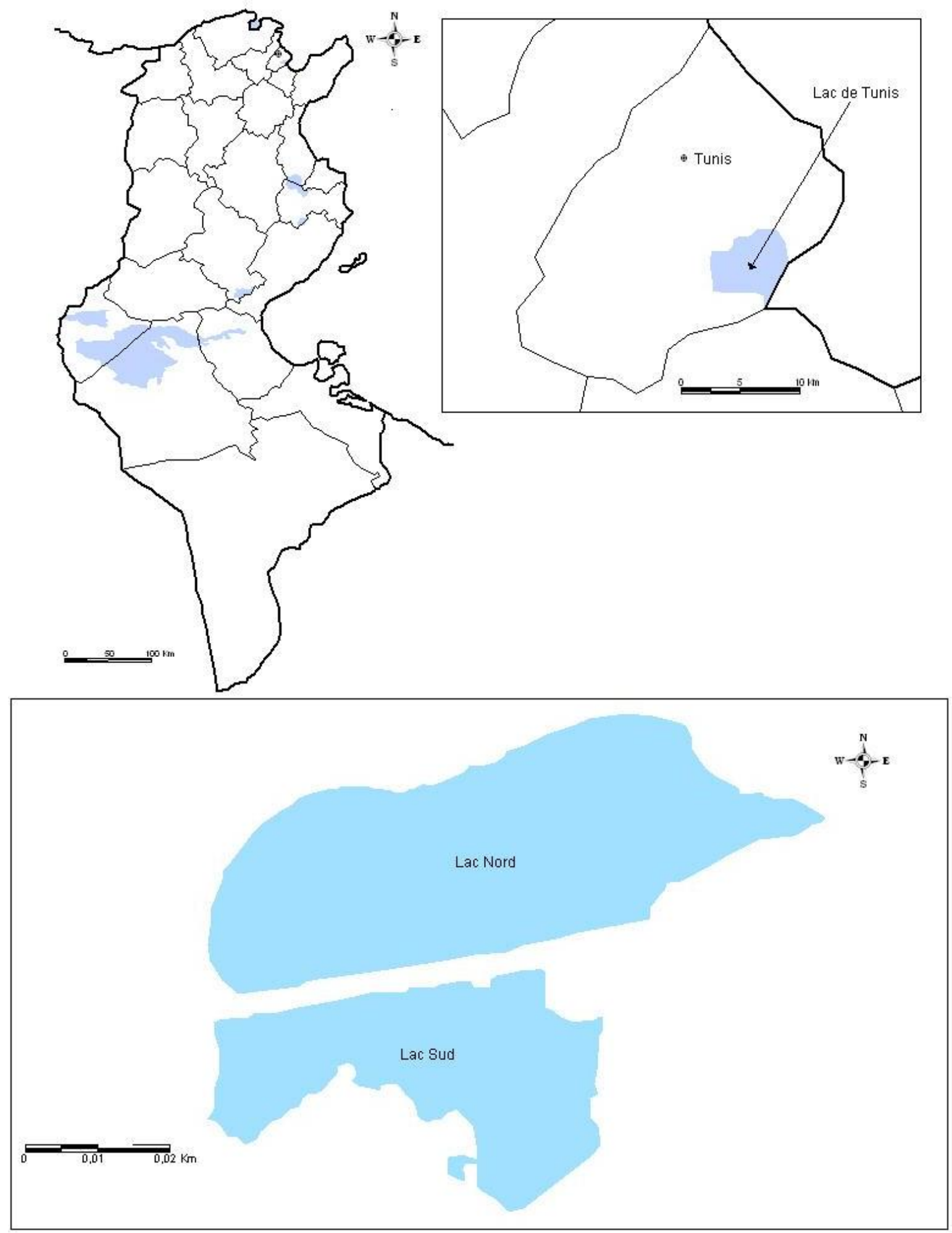

Map 1. The lake of Tunis.

ex-president. To show his talent in the field of planning, O.-C. Cacoub played on the environmental element; he tried to keep the environmental aspect of this lagoon more than to put her to the advantage of the urbanization of Tunis. Of 300 ha of space earned by the treatment of organic muds in the sector southwest, only 110 were 


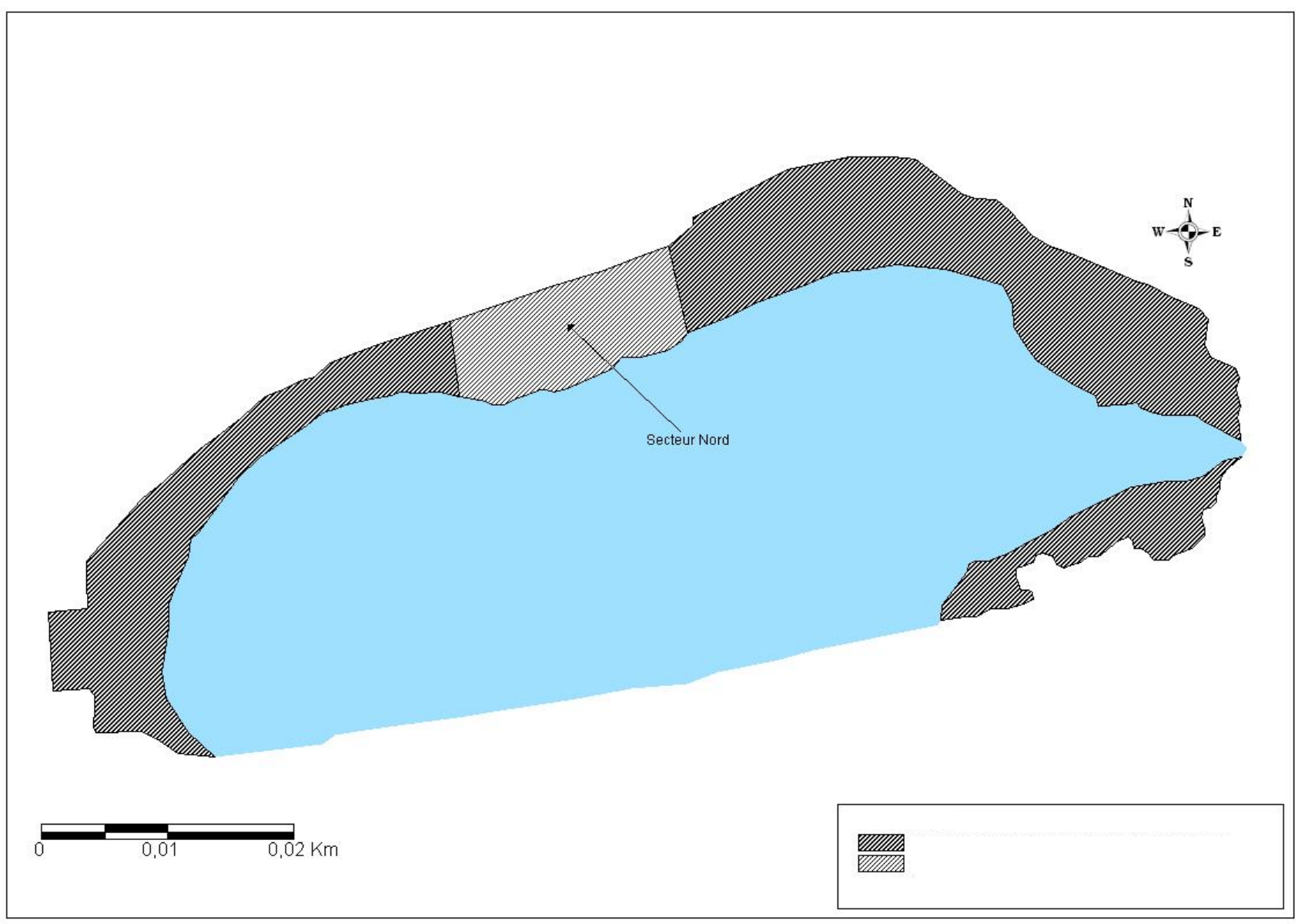

Map 2. The area recovered after the restoration of the lake.

devoted to the building and the rest would be dedicated for the production of green areas. It is a very ambitious program which imposes a very expensive blow exceeding widely the capacity of the State. However, with the application of collectivism as model of development, the development of banks becomes a dream far from being fulfilled. Thanks to the liberalism and encouragement that was granted to the foreign investments, that the State could attract the attention of the investors to invest into the urban area of the North banks of the Lake. It is in this context that $\mathrm{H}$. Barreth, who was made responsible for finding a conception of the development of the Lake, could persuade the Saudi to come to invest in this type ofdevelopment but apart equate with the Tunisian State.

\section{The building of a city moved forward on the water on the North banks of the Lake}

To be able to identify and locate the operation of The North banks of the Lake of Tunis in its urban frame, we thought of the notion of "new city ". Also, it seems interesting to display, even shortly, the definition of this concept, to see its nature and its reason to be.
In fact, to construct "new cities", well-known in the Western world, was at the origin of necessity to produce a space capable of absorbing the urban troubles of the big cities. This action becomes apparent with the will to orientate the urban growth of big agglomerations, incoherent in most cases and to limit the demographic growth resulting especially from the attraction of places.

The first essays to create "new cities" dated to 1944 with British experience in urban planning. Indeed, with "demographic boom" and growth of the urban population of industrial countries, the ambition was then to do new areas up to absorb the concentration of the population of the big cities. "The first generation of English new cities appears as a way of loosening the capital of London and the absorption of population growth" (Brissy Y., 1979). These are cities done up with the intention of welcoming the inhabitants and constructed on the basis of a demographic element.

With the beginning of 1950 s and the development of the tools of planning as well as conscience of the planning with a view to produce properly independent

${ }^{1}$ Brissy $Y$, The new cities: the role of the State and of local authorities, Berger Levrault, p23. 
Table 1. The Lake in demographic networks of first six cities in Tunisia.

\begin{tabular}{lc}
\hline Commune & Population (in thousand) \\
\hline Tunis & 674.1 \\
Sfax & 230.9 \\
Ariana & 152.7 \\
Ettadhamen & 149.2 \\
Sousse & 125 \\
Kairouan & 102.6 \\
Les berges du Lac & $220^{*}$ \\
\hline
\end{tabular}

Hagui A., source : INS, 1994.

cities from the power exercised by big agglomerations, worry to include the economic dimension next to the demographic element, was more and more present in the process of edification of these urban housing complexes. It is in these new areas that the future inhabitant finds equipment and necessary installations for his daily life. He can live there and meet his daily needs (job, leisure, animation).

"The adoption of the concept of "new city" is, on the theoretical plan of urban development, the biggest fact of postwar years. For the first time, they move away from natural process by another, volunteer, that consists in creating a new urban area, conceived rationally and understanding all installations necessary for the life of the inhabitants" ${ }^{2}$. They are therefore areas which have very particular urbanistic options which confer on them an independent character of big agglomerations. It is a new stage which marks the urban phenomenon of the Western world since it consists in producing a sophisticated city that can play the role of "city-mother".

Generally, the appearance of "new cities" is at origin a desire trying to organize the urban development of the big cities while limiting rocking between centre and periphery. In Tunisia, coastal region, notably the Region of Tunis, constitutes a big delightful pole for the population so as to know a dazzling macro cephalic. Indeed, various differences mark the governorates of this pole at the level of characteristics and processes of urbanization.

For the capital, it was the point where they recorded a request exceeding offer widely, that is at the level of accommodation, of job, as well as point where the most important part of fluxes property, of activities and of persons concentrated.

Indeed, since the beginning of 1970s, the city of Tunis has known changes which were at the origin of violent transformations at the level of its urban situation. It is with the rocking of the ecosystem of the Lake and problems procreated at the level of the proliferation of insects and

${ }^{2}$ Chaline C, The new cities in the university world, Paris, Press of France, p.45. the clearing of bad smell that the State got involved on all fronts for the cleanup of this lagoon.

At the end of 1970s, and with the cleanup of the Lake, there was a presence of the whole capable fringe in urbanization. It is here that the representatives for the action of planning wanted to include this space rectified in the Tunisian urban cloth to regulate problems linked to urbanization.

Today and with the urbanization of the North sector of the rectified banks, some people think that the Lake is at the origin of a city district and of others think that the urbanization of banks, in the Northeast / Southeast sectors, is intended to create a "new city". "Although the plan of development of the banks of the Lake includes green and entertaining areas, nonetheless it is about a plan intended to create a "new city". It is, mainly, about the operation of the banks of the Lake, which was wanted by his promoters as a "new city" of 200.000 inhabitants and including offices and trade" ${ }^{3}$ (Urbaconsult,Uram et Brammah, 1996).. Or else sign of time or time signs, mega plans are on agenda. If there is something that will take out Tunis from the simple status of sunny province, it is well that of the development of the banks of the Lake. Everything to the antipode of "spontaneity", it is a new resolutely modern city which takes shape in "the most perfect agreement ", as it is bet. It is Tunis, but another Tunis that becomes established, piece by piece on the banks of the North Lake.

At the moment, the plan is only a quarter away of its realization. A quarter already inhabited visited and coveted. (The press, El Bouhaira: the Lake of signs, March 18th, 1998).Generally, the process of creation from cities to Tunisia is always tributary on public power, it can be considered as such only by a purely administrative act. However, with the development of the urbanization of some city districts, authorities were obliged to establish them in communal status.

Examples are numerous, but the case of the district of Ettadhamen is very significant. It is a district making on integral part of the city of Tunis, counting 2500 inhabitants in 1975 and 149.000 inhabitants in 1994. It was established as a village only in 1985 . This did not prevent the researchers and the intellectuals from calling it "a city mushroom ${ }^{4}$ (Belhedi A., 1989)..

However, with the program of development and the will to settle more than 220.000 inhabitants, the Lake of Tunis is going to occupy, the third rank after the city of Tunis and that of Sfax. It is a true "new city" which is in the process of marking this rectified space spirit to mark this rectified space (Table 1).

\footnotetext{
${ }^{3}$ Urbaconsult Uram and Brammah, Study of the Diagramme Manager of Development of Big Tunis, final report of first stage, Tunis 1995-1996. ${ }^{4}$ Belhedi A, Space and society in Tunisia: Development Organisation and Development of the space in Tunisia since independence, flight III, Faculty of Letters and of Human and social Sciences, Univ. of Tunis I, p.5.
} 
Table 2. The Lake and the French new cities.

\begin{tabular}{lccc}
\hline City & Inhabitant & Accommodation & Job \\
\hline Cergy & 200.000 & 17.900 & 35.000 \\
Evry & 500.000 & 12.750 & 30.500 \\
SQY & 320.000 & 20.050 & 24.000 \\
Marne la vallée & 400.000 & 16.200 & 22.400 \\
TL & 107.000 & 15.400 & 20.000 \\
Lille Est & 100.000 & 6.150 & 7.160 \\
Lac de Tunis & $220.000^{*}$ & $37.000^{*}$ & $150.000^{*}$ \\
\hline
\end{tabular}

Hagui A., source : Chatin C (1975). 9 new cities: a French experience of town planning, Collection aspect of the urbanime * Realized from the documents of the SPLT.

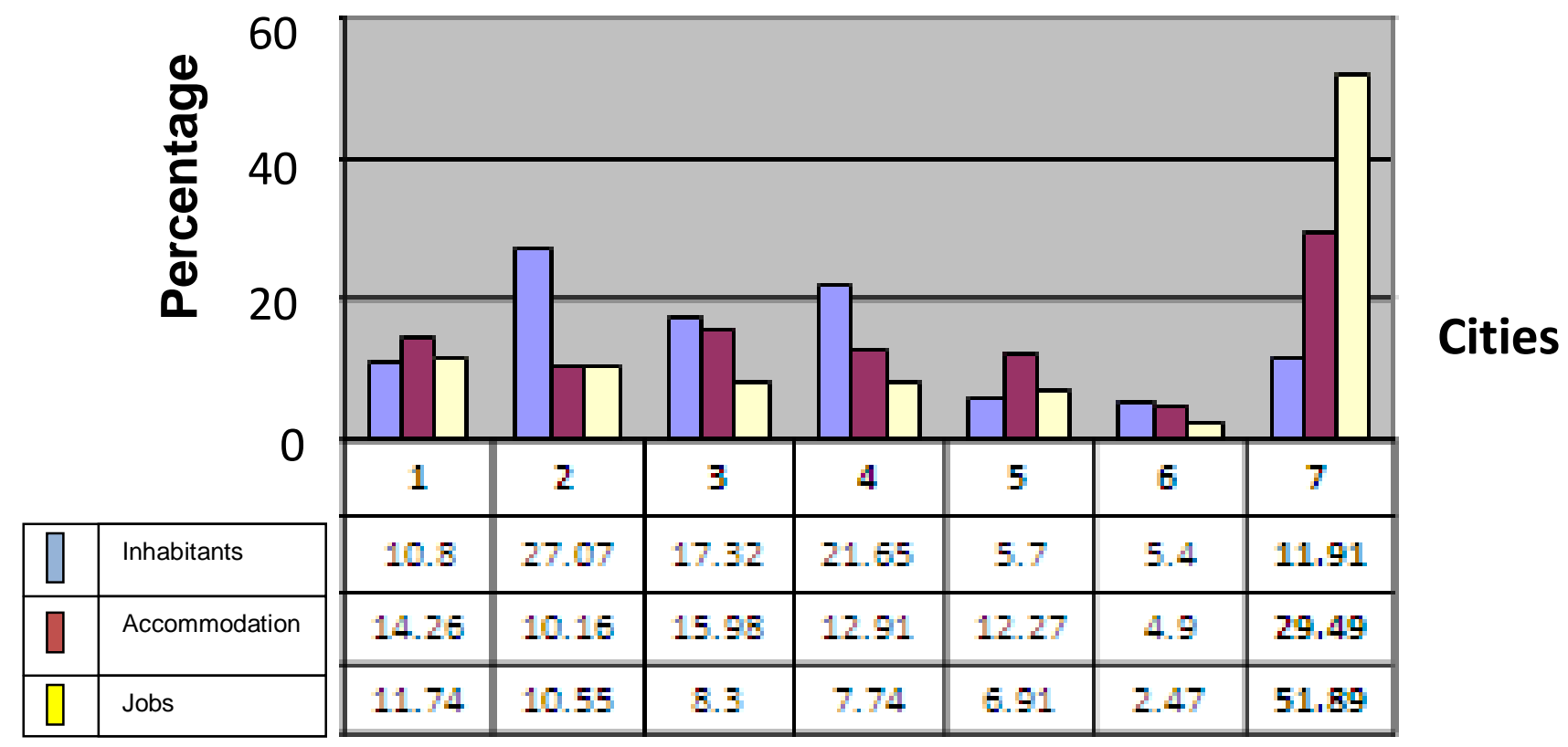

Figure 1. The Lake of Tunis in the process of creation of "new cities. Conception and realisation : Hagui A.

Also, it is true that the banks of the Lake are broken up at the level of conception, but it is possible to speak only about a plan of development of the whole space entity. It seems to us interesting to undertake a simple comparison between the program of development of the rectified banks and that of "new cities" in the world, while taking as French model which is widely inspired by the British one, so that we could prove the term "new city" on the urbanization cast on this rectified space (Table 2 and Figure 1).

Today, banks are almost urbanized. The division of conception between three designers at the same time and the break recorded at the level of its urban continuity puts us facing the importance to measure the effectiveness of this operation of development by means of a valuation which tries to put in adequacy the envisaging, already seen, and the accomplishing (Maps 3 and 4).

\section{THE LAKE OF 1990s AND THE LAKE OF 2000s: IN THE SHADE OF THE PLAN OF THE CENTURY}

What drew our attention during all our inquiry was the important number of places closed in the space of the lake. Are they then places which haven't been dedicated for an urban activity yet? Or which are until recently Opened and their closings being dictated by problems peculiar to activity? These questionings are going to allow us to see if the space of the lake is exploited well and the closing was of pure economic reasons peculiar to establishments or the opposite.

Always starting from our prototype, the Lake Luxury hotel is the main commercial place of this, it is not possible to visit the Lake without passing through this place. At the beginning of 1990s, this space counts 101 boutiques of luxuries specialized mostly in the trade of clothing, places are complete and no representatives 


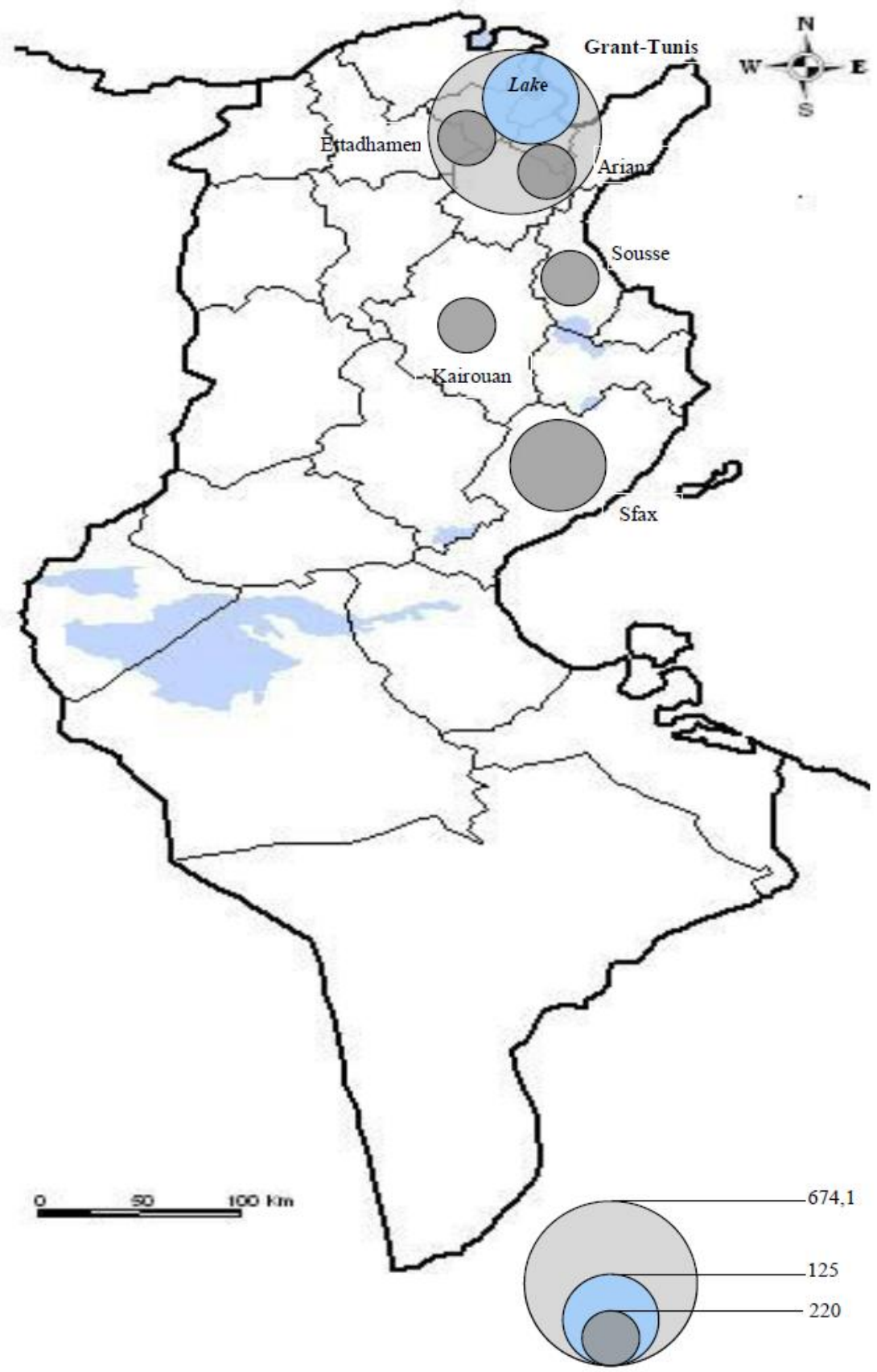

Map 3. The demographic weight of the Lake of Tunis.

think of transferring its activity out of this space. Today, 46 places, of 101 already mentioned, are empty without any activity. By questioning the neighbors, the leaders of establishments, it seems that the space of the lake does not answer the expected activities, at present, with strong value of investment.

\section{The lake of 1990s: The "success"}

We were based on the story of the leaders of establishments and employees to identify the vocation of places: particularly those that are empty today. All this, to introduce reasons which led to the closing and to the transfer of some activities. This step will serve us as base to identify the glorious decade of the lake of Tunis, 1990s.

Who can invest in the "yesterday" Lake and who can resist competition, an affirmation peculiar to an employee of the SPLT and who puts us in front of a lake of big importance and which requires a strong value of 

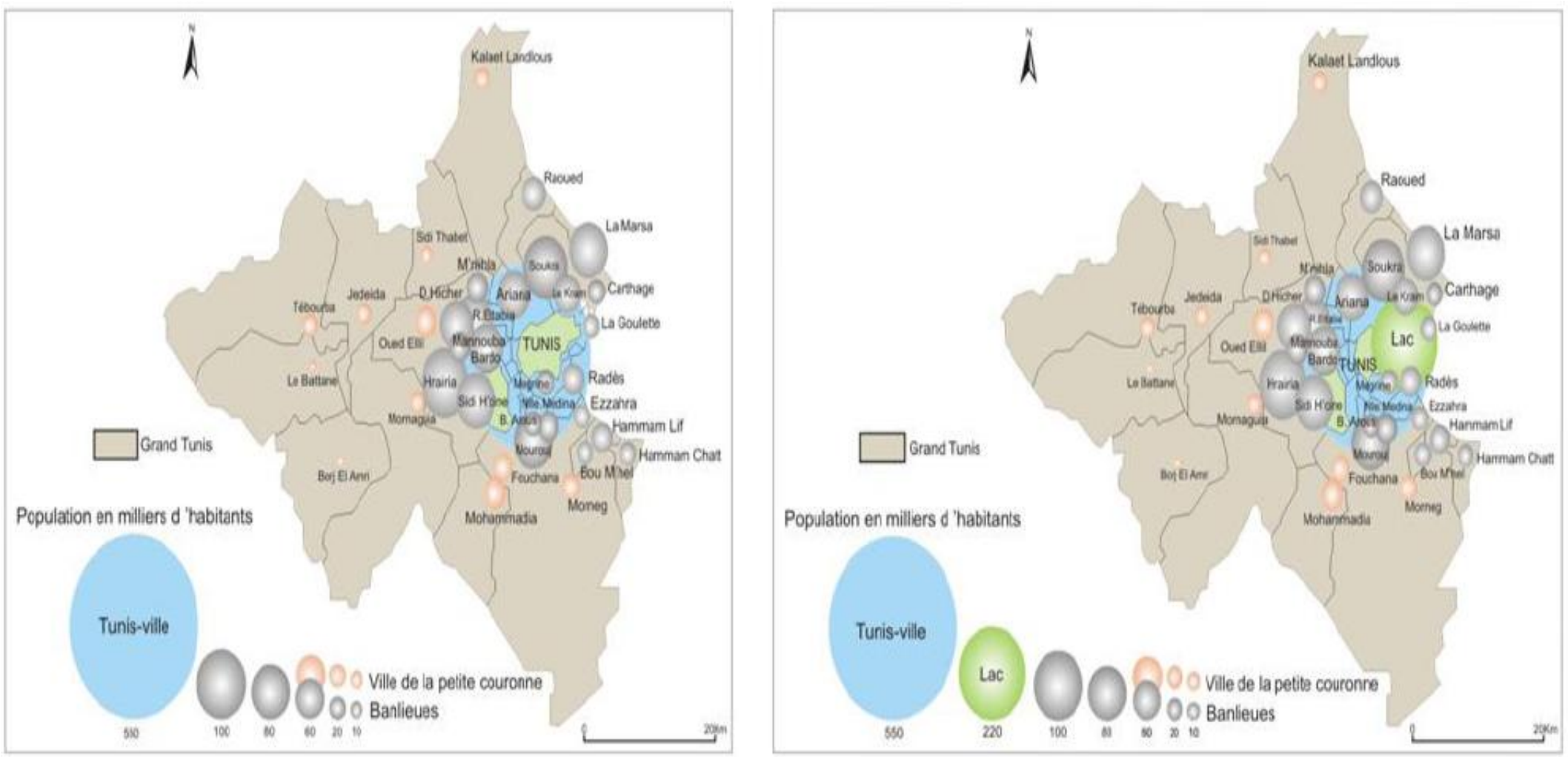

Conception and realisation : Hagui $A$

basemap card used by Habib Dlala: issues of an organization and a metropolitan development

Map 4. Communal population of Grant Tunis and the projected place of the lake (realisation Hagui A.)

investment. It is in the course of 1990s, that SPLT succeeded to make this marshy zone a place of prestige and this across the evolution of the rhythm of sales of lots provided with main services at the time when the population expressed its "fright" at being settled in wetlands.

What is important in the course of this period was the appearance of the phenomenon of reaffectation of places that made nothing but the strengthening of the place of the activities of strong value of investment in the most profitable places.

The land market of the lake: a low-priced lake!!! to guarantee success

At the beginning of the marketing of fields recovered by the development of the banks of the lake and with a view to drawing the attention of customers who are not in agreement with this type of development, SPLT adopted a strategy which consists in giving lots of fields provided with main services at a low price which hardly exceeds 50 dinars $/ \mathrm{m}^{2}$

A considerable plan of investment introducing fields of 50 dinars $/ \mathrm{m}^{2}$ in the time when $\mathrm{m}^{2}$ 
Table 3. The purchase price of $\mathrm{m}^{2}$ fields of the banks of the Lake.

\begin{tabular}{lccccccc}
\hline \multirow{2}{*}{ Years } & \multicolumn{7}{c}{ The price of fields $\left(\mathbf{D} / \mathbf{m}^{2}\right)$} \\
\cline { 2 - 8 } & $\mathbf{5 0}$ & $\mathbf{5 0 - 2 0 0}$ & $\mathbf{2 0 0 - 4 0 0}$ & $\mathbf{4 0 0 - 6 0 0}$ & $\mathbf{6 0 0 - 8 0 0}$ & $\mathbf{8 0 0 - 1 0 0 0}$ & Plus que 1000 \\
\hline $1987-1990$ & 20 & - & - & - & - & - & - \\
$1990-1993$ & - & 24 & - & - & - & - & - \\
$1993-1996$ & - & 25 & 30 & 50 & - & - & - \\
$1996-1999$ & - & - & 15 & 35 & 45 & - & - \\
$1999-2002$ & - & - & - & 16 & 10 & 20 & - \\
$2002-2005$ & - & - & - & - & - & 18 & 22 \\
Après 2005 & - & - & - & - & - & - & 4 \\
Total & 20 & 49 & 45 & 101 & 5 & 38 & 26 \\
\hline
\end{tabular}

Source : Hagui A., study of the results of the inquiry.

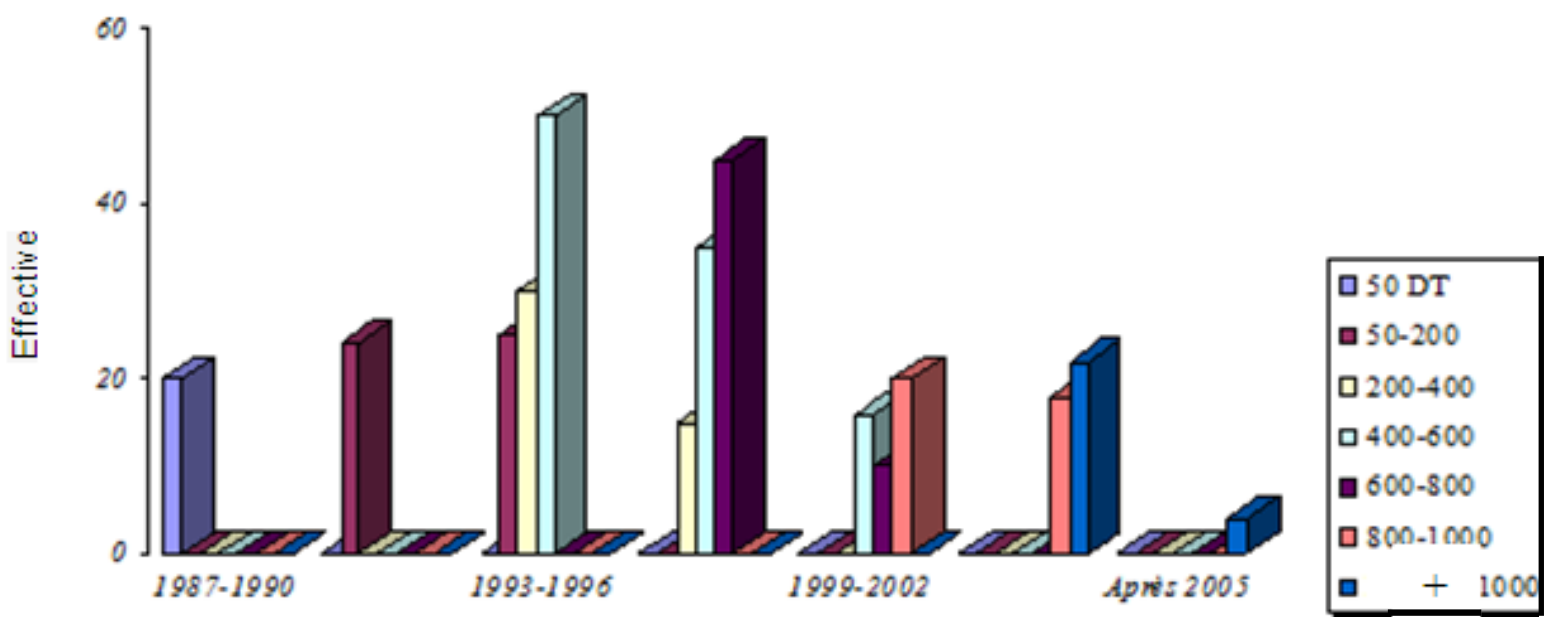

Figure 2. The taking of fields.

exceeded 100 dinars widely in several places of the city. A strategical choice which hides the whole ambition which tries to make "seduction" a means to attract looks towards this space. All this at the time when we know very well that SPLT is a commercial firm which tries to make benefits without thinking even of the social level.

It is true that SPLT started the marketing of the fields of the North sector of banks rectified with prices more adequate to the financial capacities of the medium social classes. Prices which did not exceed 50 dinars/ $\mathrm{m}^{2}$ and this was at the origin of a prospective vision which tries to seduce the customers who were haunted by a bad history with the marshy zones. Succeeding in the attention of these customers, prices will progressively evolve with request. (Maintenance accomplished with Med. Ali T., administration officer in SPLT, on the 7 June, 2006). The inquiry that we had led, allowed us to raise Table 3 and Figure 2. Starting with a price of $50 \mathrm{D}$ and arriving to a price of more than $1000 \mathrm{D} \mathrm{m}^{2}$, we can say that SPLT could recompensate the operation of the North banks of the lake due to the fact that $58.62 \%$ of the investigated bought building lands with prices which widely exceed $400 \mathrm{D} \mathrm{m} \mathrm{m}^{2}$.

The land market of the North zone became in 1990s the most expensive market of the country. All in all, the success of sale explains the positive building of this space constructed at the North Lake. (Pierre-Arnaud B, 2003).

The success of sales showed during the period 1993 to 1999 when price exceeded $600 \mathrm{D} / \mathrm{m}^{2}$ to attain $800 \mathrm{D} /$ m2. These rates explain the success of SPLT to commercialize the first edge (stage) of these banks and to change the opinion of the Tunisian people vis-à-vis to waters. Indeed, the prices of the land advanced in a remarkable way according to periods. They evolved from $50 \mathrm{D} / \mathrm{m}^{2}$ for the period 1987 to 1990 to $200 \mathrm{D} / \mathrm{m}^{2}$ for the period of 1990 to 1993 , and from $400 \mathrm{D}$ for 1993 to 1996 to $800 \mathrm{D}$ for 1996 to 1999 . During all the period of 1990 s, the success of sales in high prices testifies a request Hence, becoming the most expensive land market not only of the capital but still of all country. Is the space of the lake going to be able to answer the expectations of 
Table 4. Rate of answers of the leaders of establishments.

\begin{tabular}{lccccc}
\hline \multirow{2}{*}{ Activity } & \multicolumn{3}{c}{ Trading } & \multicolumn{2}{c}{ Offices and services } \\
\cline { 2 - 6 } & $\begin{array}{c}\text { General } \\
\text { feeding }\end{array}$ & $\begin{array}{c}\text { Trade } \\
\text { of clothing }\end{array}$ & Restauration & $\begin{array}{c}\text { Care of } \\
\text { health }\end{array}$ & $\begin{array}{c}\text { Financial } \\
\text { service }\end{array}$ \\
\hline Rate of answer & 12 & 105 & 5 & 15 & 10 \\
Total of investigatinon & 25 & 155 & 20 & 37 & 33 \\
\hline
\end{tabular}

Hagui A., source: study of the results of the inquiry.

its new conquerors?

\section{Unexpected windfall profits and unforeseen turnovers}

To know the importance of the site of the lake from an economic point of view, our step consists in questioning the different leaders of establishments about turnovers accomplished for the last months, in even looking at the last years.

It is via the study of results that it was possible to distinguish between the lake of 1990s and that of the present in spite of a partial refusal to answer the question concerning the turnovers. Indeed, for the trading and on a total of 200 investigated establishments, 122 only that is $61 \%$, assessed their accomplished turnovers and gave us even predictions. As for the activity of office and of service, $35.71 \%$ helped usassess their turnover that is 25 establishments on a total of 70 .

However, gathered information was precious and of a great value, we introduce them in (Table 4). Of a total of 147 establishments, $59.18 \%$, that is 87 establishments, have monthly turnovers which widely exceed $2000 \mathrm{D}$ to the point of achieving, sometimes even, 3000D.

Generally, the reading of Table 4 allows us to draw the following conclusions:

1) For the trading activity, only general alimentation has a business figure which does not exceed 1500D / month among which $66 \%$ that is 8 of a total of 12 establishments; accomplish a turnover which is included between 500 and 1000D. As for the trade of clothing, the variety of turnovers is in relation with variety and quality of articles put for sale. Generally, their turnovers vary between 1000 and more than 3000 dinars / month, which more than $44 \%$ (47 establishments of 105 investigated) have a business which exceed 2500D. Finally for 5 investigated restaurants, the so declared accomplished turnovers did not show 2500D / month which the figure of some are included between 1500 and 2000DT /month.

2) Concerning the activity of office, estimates were included between 1500 and more than 3000D / month. Indeed, 44\% accomplished turnovers which exceeded $3000 \mathrm{D}$ against $20 \%$ for business which were included between 2500 and 3000D. For the services of care, represented especially by the laboratories of analysis and the medical practices of free practice, alone $26.66 \%$ declared to have turnovers between 2000 and 3000D. This fall in comparison with other services is explained especially by the absence of visitors. Services not much used by the patients for reasons linked especially to specialization. Taking here as the model of the veterinary service which cater only for well-off. Finally, the financial service which includes accountancy, expertise, their turnovers, according to the inquiry, did not exceed 3000DT / month, among which $70 \%$ have figures which exceeded 2000 and the $30 \%$ which remain less than 2000D.

These turnovers, already taken out again from the inquiry, and from the current situation of the different establishments, which we can say that the lake of Tunis knew its economic boom during the decade of 1990 to 2000.

It was not easy to believe in it: with a Lake where everybody wants to go there, to gain a benefit or an article, the "inversion" was incredible.

In fact, for the years which succeeded the marketing of lots and the starting of buildings, the 1990s, the lake was a place of investment by excellence. All tradesmen and the owners of the big boutiques want to acquire or even renting a place there. The rhythm of sales, the accomplished recipes, explains well this tendency.

Look around you, you can even count people. There is this impression that the lake was emptied of its users. It is as if it were a "product" which was completely to be consumed by the Tunisians. (Aymen, dealer, maintenance accomplished on March 15th, 2007)

Also, to know the economic importance of the lake, we keep the following stories which are of a big importance:

The first is to describe the conflict between SPLT and the opinion of the Tunisian people in relation to wetlands. Indeed, it is across the press and the advertising magazines that this state organism succeeded to change this attitude by commercializing this urban product.

Before I had a boutique in Bardo and I saw in the press and the advertising magazines that the lake is going to become a place of luxury as El Menzah and El Manar. Really I thought, at that time to buy a lot of commercial, but nobody in my family and my friends was in my side even if those prices were accessible. It is a zone where there was the problem of waters rising.

Then, I saw, in the press, that the rhythm of sale 
Table 5. The turnovers of different activities (1990 to 2000).

\begin{tabular}{|c|c|c|c|c|c|c|c|}
\hline \multirow{3}{*}{ Type of activity } & \multicolumn{7}{|c|}{ Business figure } \\
\hline & \multicolumn{7}{|c|}{ in $10^{2}$ dinars / month } \\
\hline & $5-10$ & $10-15$ & $15-20$ & $20-25$ & $25-30$ & 30 et plus & Total \\
\hline General feeding & 8 & 4 & - & - & - & - & 12 \\
\hline Trade of clothing & - & 5 & 10 & 42 & 32 & 15 & 105 \\
\hline Restauration & - & - & 3 & 2 & - & - & 5 \\
\hline Care of health & - & - & - & 1 & 3 & 11 & 15 \\
\hline Financial service & - & - & 3 & 5 & 2 & - & 10 \\
\hline Total & 8 & 9 & 16 & 50 & 37 & 26 & 147 \\
\hline
\end{tabular}

Hagui A. activities service sectors established on the North banks of the lake of Tunis: radiance and zones of influence, seminars on "the aspects of urban development", research unit City, Planning and development (VAD).

evolved and that situation and vision in relation to the lake changed. I was afraid to miss this occasion. Even if there were risks, I contacted SPLT and I bought a lot. (Abir C., shopkeeper, maintenance accomplished on May 7th, 2007).

Then, we will try to show the success of first stage of marketing and passage in speculation. The one who gives more and who has "interventionist" power multiplies these chances to acquire a lot in the space of the lake:

You leave Marsa, El Menzah, El manar, and you invest in a properly marshy zone. I even do not succeed in accepting this idea and to put myself into this wetland.

Today you find me here, in the lake of Tunis, with this commercial place that I bought for $650 \mathrm{D} / \mathrm{m}^{2}$. I refused to buy it at $50 \mathrm{D} / \mathrm{m}^{2}$ to buy it at 650 with the intervention of the big representatives. The money for the purchase of a lot will not be enough for you. Before, if I had the commercialism, I will not miss the opportunity which was given by SPLT during the beginning of marketing. (Ali G., dealer, maintenance accomplished on June 2nd, 2007)

Is it then a place which answered the expectation of activities and of persons? According to the witnesses, he was as such:

In a simple comparison, I am going to show you the place of the lake in comparison with other places of the capital.

At the time when I rented this place, in 1995, I had others in El Manar and in Marsa. The recipes of sales of three places were as follows: less than of 2000D / month, on average, for both places of El Manar and of Marsa and more than what $3000 \mathrm{D} /$ month for this last during the years of 1995 to 1999 . It was really a considerable place of investment. Its importance exceeded that of places very known of the capital. It is a business place by excellence. (Med. T., business man, maintenance accomplished on June 10th, 2007)

According to the result of our inquiry and discussions led towards different social categories, dealers, businessmen, possessing places, " the urban history" of the lake knew two stages: that of development " and of "success" of the operation of 1990s marking the "yesterday" lake, and that of "today's" translating "bankruptcy" and crisis of establishments.

\section{The Lake of 2000s: "bankruptcy"}

\section{A falling affair figure and a worrying situation}

It is of great reminder that the banks of the lake in its North sector were a success which was at the origin of a big request of building lands. However, current situation differs from the one that succeeded, due to the fact that $37.20 \%$ activities, notably salespersons, were transferred towards other zones for properly economic reasons linked to the economic "non-profitability" of this space following in a business figure which is going down.

From a lake where more than $76 \%$ activities accomplished turnovers which widely exceeded $2000 \mathrm{D} /$ month to reach even more than $3000 \mathrm{D}$, to other one where more than $56 \%$ of establishments recorded figures which hardly exceeded $2500 \mathrm{D}$ to the point of achieving $500 \mathrm{D}$. (Table 5, Figure 3 and 4)

A more and more worrying situation especially with the current tendency of activities which was introduced at the level of the stories of the owners and of the tenants of places:

It is true that the lake has not been yet built yet at the level of both parts which are under way of realization, but I can't stay here until this zone is more delightful and more attractive. They have rents to be paid and if my activity doesn't succeed in accomplishing recipes which allow me to resist, [he uses the term of resistance for us 
(1990-2008)

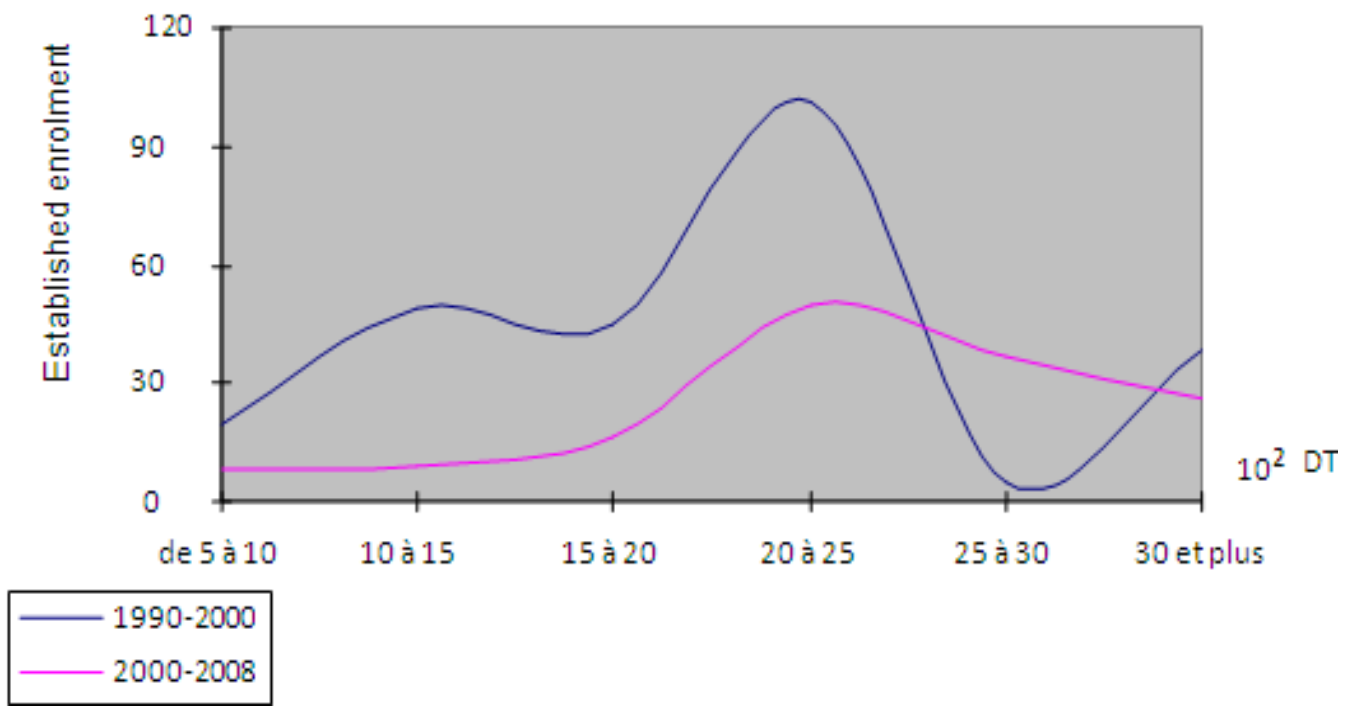

Figure 3. The variation of turnovers Source: study of the results of the inquiry, conception and realisation: Hagui $A$.

to explain the necessity to make benefits which allow to stay with his activity in this place], what is the use to stay here, it is better to search other more favorable places. (Haeckel, tenant of commercial premises, maintenance accomplished on May 25th, 2007)

Following an interview with Mr. Ridha T., a dentist who became established in the banks of the Lake at the end of the year in 1993, he explains to us the state of the lake since his "conquest" by activities until our days:

He has only to look at streets with me, they are almost empty. I cannot go for a walk without a companion. You have the feeling of insecurity with this space [risks of robbing increase with empty streets, in the majority of the time]. That is the lake!!! I am a part of the first inhabitants, I live and I work here and I know this place very well since its creation. Really it is incredible, thousand of millions of Tunisian dinars were invested to construct Arrous El Moutawasset [in Tunisian dialect the wife of the Mediterranean] and instead of constructing it, they made the Lake unbearable.

It was better to clean it up and without urbanizing it. Ridha T., dental doctor, maintenance accomplished on June 15th, 2007)

All stories are significant, but we also keep that of Mr Ali $\mathrm{K}$., tenant of a place of general nutrition, which shows us the current situation of the lake of Tunis which clears itself by the appearance of a desire, especially that of dealers, to transfer activity out of this space:

I discussed with an owner of a commercial lot to see the possibilities of renting it. Everything is good, but there is just a small problem concerning the price of the renting which exceeds slightly the price of this place. In any case I am going to rent it even if he does not reduce the price of the renting, so that I could get away of' El Mouchkla (in Tunisian dialect problem).

For me, the Lake has not succeeded, for these last years, in meeting the needs of all activities, without exception, as far as clients are concerned. It is necessary to search other solutions in other more animated places. (Ali K..., (tenant of a place of general feeding, maintenance accomplished on May 2nd, 2007) Immediate consequences of this situation which includes all urban functions were at the level of the appearance of the phenomenon of functional migration following in the transfer of activity.

Of speculation and competition between activities for a better location to reach at an optimum profitability, at a migration of activities towards other places of the capital more profitable and more animated, we say that "The urban history" of the lake, in its North sector, was mark by an escape "and migration "of establishments. (Plate Hagui A.) Photos: The financial status of the establishments of the North banks of the Lake: move and transfer of activity (Figure 4).

\section{From the conquest to the "escape ": The countdown!!!}

From a place of a great value of investment to another with a declining economic profitability we ask about the degree of resistance of activities to this deterioration which increases from day to day? It is across this reflexion which tries to prove the current tendency of 

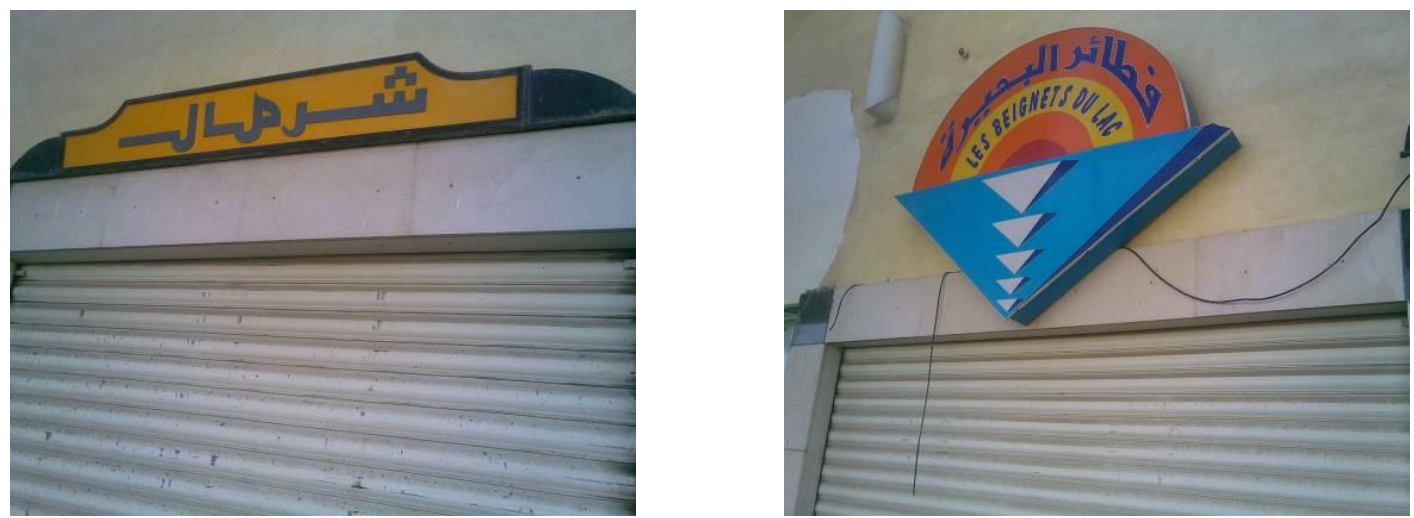

Enclosed spaces and activities that were transferred to other places in the capital more "profitable
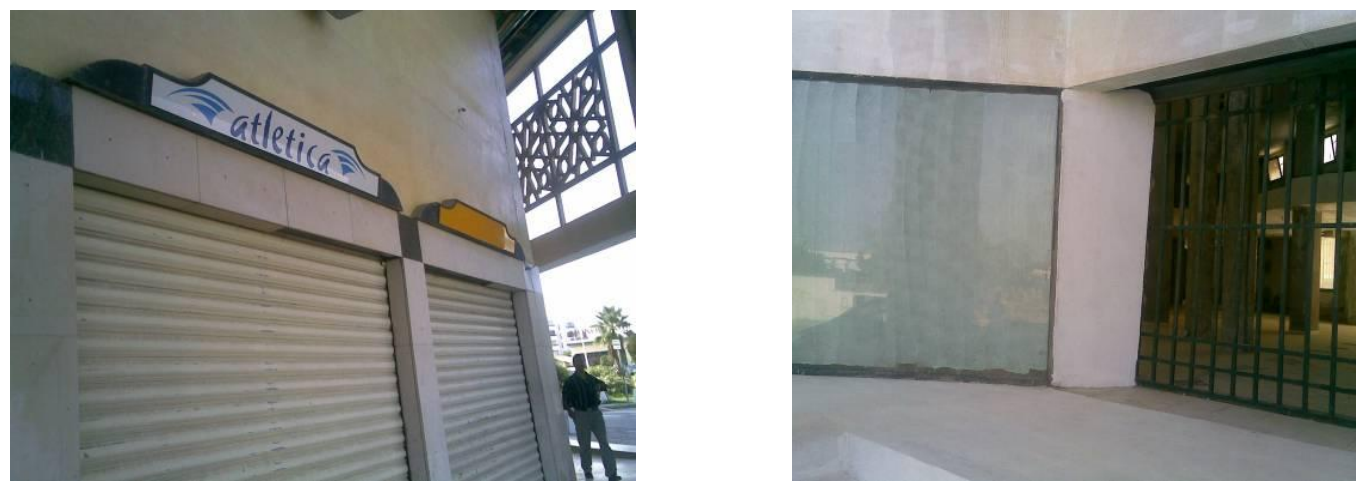

At the entrance to the "Lake Palace", closed or being rebuilt to be more compatible to the needs of business
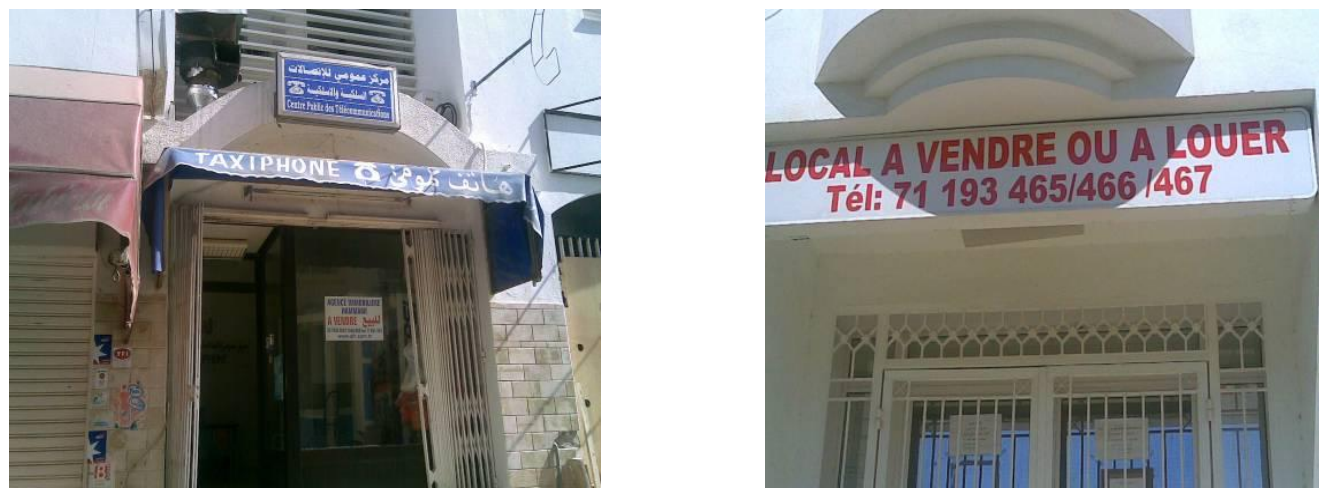

The sale or rental of premises reflects the situation of Lake postmarketing. Havepremises which have been neglected by their activities following a "bankruptcy".

Figure 4. (Plate Hagui A.) Photos: The financial status of the establishments of the North banks of the Lake: move and transfer of activity.

On a total of 430 establishments, 160 , that is $37.20 \%$, were transferred towards other places other than that of activities, that it was possible to regroup results (Table 6). the lake. This transfer is explained by the turnover accomplished in the 2000s. The analysis of the migration of establishments by edge of activity shows us the preponderance of the places of the trade of clothing among which the part of transferred activities widely exceeds $42 \%$, that is 116 of 271 establishments.

This transfer has affected all the activities inquired about. As for the general nutrition, out of 31 institutions, 6 activities have changed their location, that is to say $19.35 \%$ of the totality. For the financial and care services, this transfer has affected successively 26 and $31 \%$ of the activities.

Finally, as for the activity related to restaurants and 
Table 6. The turnovers of different activities (2000 to 2008).

\begin{tabular}{lccccccc}
\hline \multirow{2}{*}{ Type of activities } & \multicolumn{7}{c}{ Business figure in $\mathbf{1 0}^{\mathbf{2}}$ dinars / month } \\
\cline { 2 - 8 } & $\mathbf{5 - 1 0}$ & $\mathbf{1 0 - 1 5}$ & $\mathbf{1 5 - 2 0}$ & $\mathbf{2 0 - 2 5}$ & $\mathbf{2 5 - 3 0}$ & $\mathbf{3 0}$ et plus & Total \\
\hline General feeding & 12 & - & - & - & - & - & 12 \\
Trade of clothing & 5 & 47 & 40 & 13 & - & - & 105 \\
Restauration & 4 & 1 & - & - & - & - & 5 \\
Care of health & - & - & - & 1 & 4 & 10 & 15 \\
Financial service & - & - & 6 & 4 & - & - & 10 \\
Total & 8 & 9 & 16 & 50 & 37 & 26 & 147 \\
\hline
\end{tabular}

Hagui A. Centrality of the lake and the centrality of Tunis: a complete "face-lift" of the capital, act of introduced seminar by «the University of the Spring» on urban plans and organised by the Tunisian Association of the Town planner (ATU), source: study of the results of the inquiry

Table 7. The current tendency of the urban activities of the Lake of Tunis.

\begin{tabular}{|c|c|c|c|c|c|c|c|}
\hline \multirow{3}{*}{ Type of activities } & \multicolumn{2}{|c|}{ Transferred } & \multicolumn{4}{|c|}{ Existant } & \multirow{3}{*}{ Total } \\
\hline & \multirow{2}{*}{ Effectif } & \multirow{2}{*}{$\%$} & \multicolumn{2}{|c|}{ With a tendency to stay } & \multicolumn{2}{|c|}{ With a tendency to move } & \\
\hline & & & Effectif & $\%$ & Effectif & $\%$ & \\
\hline General feeding & 10 & 6,25 & 20 & 10.36 & 5 & 6.49 & 31 \\
\hline Trade of clothing & 116 & 72,5 & 99 & 51.29 & 56 & 72.72 & 271 \\
\hline Restoration & 6 & 3,75 & 17 & 8.8 & 3 & 3.89 & 26 \\
\hline Care of health & 13 & 8,12 & 29 & 15.02 & 8 & 10.38 & 50 \\
\hline Financial service & 15 & 9,37 & 28 & 14.5 & 5 & 6.49 & 48 \\
\hline Total & 160 & 100 & 193 & 100 & 77 & 100 & 430 \\
\hline
\end{tabular}

Source: study of the results of the inquiry, conception and realisation : Hagui A.

even if the example is not really vast, 23.07 have been affected by this transfer that is 6 transferred activities of a total of 26.

What is interesting in this inquiry is that the activities ready to be transferred towards other zones, according to their institutions 'directors, correspond to $28.51 \%$ of the existing activities (Table 7, Figure 5 and Map 5).

\section{Conclusion}

At the end of 1970 s, at the time when the city of Tunis was in the middle of various problems of urban order, several factors helped make the development of the lake an operation of rescue for Tunis. Hundreds of hectares possibly cover the needs of the city at least for ten consecutive years. Stake is first-rate but the financial inability of the State to take care of all this operation, delayed the intervention on its areas recovered by the sea.

It is with a city centre in which more than $1 / 3$ of the population of agglomeration and the majority of urban activities are concentrated, notably service sectors, than it was necessary to produce other areas capable of attracting the fluxes of activities and of persons of the city centre of Tunis. And it is with the cleanup of the Lake, that it seems interesting to use the North banks to the advantage of the urbanization of Tunis. This idea appeared since the beginning of 1980s, with the creation of SPLT which must create on this rectified space the whole space capable of attenuating the hyper concentration of the inhabitants and of activities especially in the city.

On demographic plan, this operation of development is going to influence the distribution of the inhabitants in the capital. With more than 220.000 inhabitants who will be settled on the rectified banks, the distribution out of the population in Big Tunis is going to know transformations. However, the city of Tunis will lose the demographic primacy of its centre to the advantage of banks.

On functional plan and according to scheduled program, these banks are going to know an important functional weight widely exceeding the weight of the city of Tunis, notably Medina and the low city. Also they aregoing to have an important role in the readjustment of the land market of the city by absorbing the request there in $\mathrm{m}^{2}$ of urban activities of the city over more than 10 years. It is with this programming that the city of Tunis will know the appearance of the whole zone which will concentrate more than $45 \%$ workforce.

As for urban plan, this cast urbanization is going to open horizons towards the conquest of the Eastern areas 


\section{Effect}

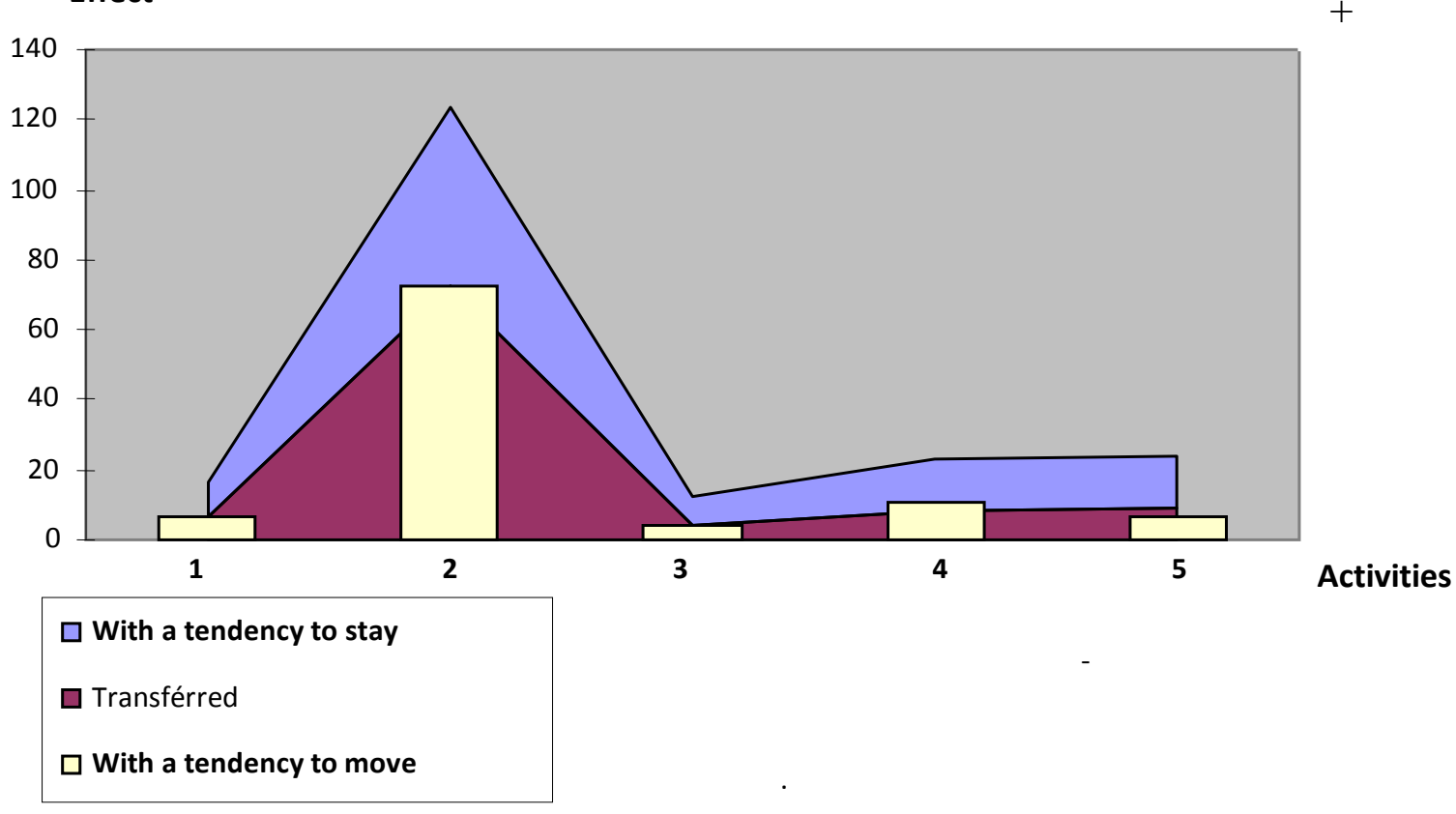

Figure 5. The recent tendency of the different activities of the north bank sector. Source : study of the results of the inquiry, conception and realisation: Hagui A; 1) General feeding; 2) Trade of clothing; 3) Restauration; 4)Care of health; 5)Financial service.

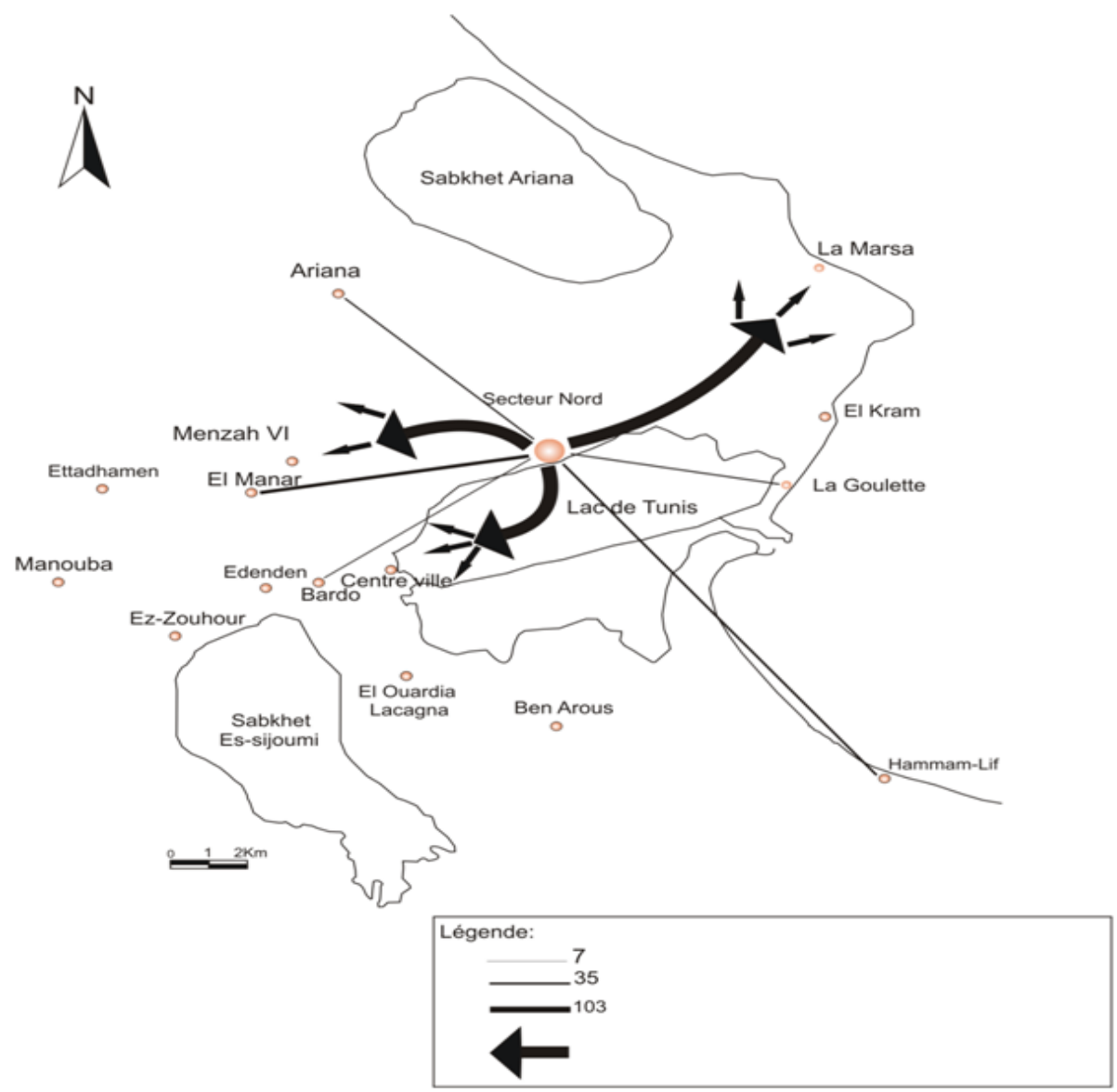

Map 5. The activities of the lake: the current trend. 
which were donned and affected by the proliferation of anarchic and illegal buildings. The urban extension of Tunis will be able to be performed any azimuth by breaking its linearity. Today banks are almost urbanized. The study of different urban activities showed two stages of urban development of the urbanization of the banks of the lake. For the 1990s, we speak about the progress and about the development of this urbanization. It is during this decade that the lake was considered to be the most sought place by activities and especially those with strong value of investment. This observation is relation touch with the accomplished business figure.

As for the 2000s, this urbanization has known an economic crisis which is due essentially to the decline of the turnovers in comparison with the situation accomplished in 1990. Out of this situation appeared a functional migration of institutions towards other place in the city.

\section{REFERENCES}

Belhedi A (1989). Espace et société en Tunisie : Développement Organisation et Aménagement de l'espace en Tunisie depuis l'indépendance, vol III, Faculté des Lettres et des Sciences Humaines et Sociales, Univ. de Tunis I, p.252.

Brissy Y (1979). Les villes nouvelles : le rôle de l'Etat et des collectivités locales, Berger levrault. p.254.
Chatin C (1975). 9 villes nouvelles: une expérience française d'urbanisme, Collection aspect de l'urbanime, ed. Dunod. p. 275.

Chaline C (1985), Les villes nouvelles dans le monde, Paris, Presse universitaires de France p.128.

Hagui A (2006), Les activités tertiaires implanté sur les berges Nord du lac de Tunis : rayonnement et zones d'influences, séminaires sur "les aspects d'aménagement urbain", unité de recherche Ville, Aménagement et développement (VAD), Ecole Nationnale d'architecture et d'urbanisme (ENAU) de Sidi Bou Saïd p.25.

Hagui A (2007), Centralité du lac et centralité de Tunis: un "lifting » complet de la capitale, acte du séminaire présenté par " l'Université du Printemps " sur les projets urbains et organisée par l'Association Tunisienne des Urbaniste (ATU) p.15.

Institut National de Statistique (1994), Recensement général de la population et de logement, Tunis. p. 190.

Pierre-Arnaud B (2003), Faire la ville au bord de l'eau, les lacs de Tunis: des marges urbaines à des sites de très grands projets d'aménagement, thèse de doctorats à la Faculté de Géographie, Histoire, histoire de l'art, Tourisme, Institut d'Urbanisme de Lyon, CNRS p.503.

Urbaconsult Uram et Brammah, (1996), Etude du Schéma Directeur d'Aménagement du Grand Tunis, rapport final de première phase, Tunis 2:162-233. 